\title{
Molecular Mechanisms of Obesity, Inflammation and Cancer: The Use of in vitro Model Approaches for Targeted Prevention Strategies
}

\author{
Jenifer I. Fenton ${ }^{*}, 1,2$, Sarah J. McCaskey ${ }^{1}$ and Hillary L. Woodworth ${ }^{1}$ \\ ${ }^{1}$ Department of Food Science and Human Nutrition and the ${ }^{2}$ College of Nursing, Michigan State University, East \\ Lansing, MI. 48824, USA
}

\begin{abstract}
Hormones, growth factors and cytokines produced by adipocytes are associated with cancer progression. We suggest that chronically elevated adipokines as observed in the obese state may have profound effects locally on colon epithelial cells through growth promotion effects, induction of autocrine signaling, angiogenesis and immune cross-talk. This dysregulation of the local environment via a systemic signal may lead to the promotion of colon cancer via a novel set of mechanisms. Elucidating the mechanisms by which obesity may increase cancer risk may lead to the identification of treatment/prevention targets. The use of models of this multistage process should allow for mechanism-based approaches to block phenotypes associated with the process of carcinogenesis. The review highlights using in vitro model systems of these various stages to understand the molecular mechanisms of obesity and cancer risk. The advantage in using these systems is that the response of cells possessing various transformations can be compared to "normal cells". The key is to identify targets that are aberrant from normal to perturb for cancer prevention strategies. This approach would theoretically reduce the possibility of severe or unwanted side-effects when the target does not also destroy the normal cell mechanisms. Cell models can aid in the identification of those targets and inform rationale translation to animal and human studies.
\end{abstract}

Keywords: Obesity, adipokine, cancer, colon, prostate, breast, leptin, interleukin-6, adiponectin.

\section{INTRODUCTION}

During the past 20 years, obesity has risen at an epidemic rate in the United States. Currently, 1 in 4 adults in the US is considered obese, defined as having a body mass index $\geq 30$ $\mathrm{kg} / \mathrm{m}^{2}$ [1]. Morbidities associated with obesity are second only to smoking in the US [2]. Metabolic syndrome (MS), a constellation of risk factors associated with central adiposity, has been hypothesized as the primary etiologic paradigm to explain increased risk of cardiovascular disease and type-2 diabetes in those affected. The Centers for Disease Control and Prevention estimate that approximately 47 million Americans have this condition. The clinical presentation in MS includes increased abdominal fat, elevated levels of triglycerides and low-density lipoproteins, low levels of high-density lipoprotein cholesterol, elevated blood pressure, insulin resistance, and prothrombic and proinflammatory states [3]. This insulin-resistant, proinflammatory state is also associated with elevated blood insulin, insulin-like growth factors and the adipocyte-derived cytokine (adipokine) leptin; the adipokine called adiponectin is decreased in some of those with MS. The colon is among several sites, including endometrium, breast, gallbladder and prostate, that are subject to increased risk of cancer in obese individuals [4]. Prospective epidemiologic studies have associated MS with risk of subsequent colorectal cancer and recurrent breast cancer [5-8]. The altered levels of hormones, growth factors

*Address correspondence to this author at the Department of Food Science and Human Nutrition, Michigan State University, 208B G.M. Trout Bldg, East Lansing, MI. 48824, USA; Tel: 517-355-8474; Fax: 517-353-8963; Email: imigjeni@msu.edu and adipokines may be causally related to the development of certain cancers, including colon cancer [9]. Risk of obesity-associated cancers may be causally related to the proinflammatory state.

Colon cancer has been causally linked to inflammatory conditions, such as inflammatory bowel disease (IBD). As such, it is plausible that the presence of increased serum levels of inflammatory mediators that occurs with obesity underlies the obesity-colon cancer association [10]. Casecontrol and cohort studies consistently show a clear positive association between colon cancer and/or colonic polyps with elevated levels of insulin [11,12] and insulin like growth factor (IGF)-1, as well as decreased levels of IGF-binding proteins [13]; the levels of which are altered in the obese state. However, research is lacking regarding an association between elevated adipokines and colon cancer.

A growing body of evidence associates inflammation with epithelial cell transformation and the process of carcinogenesis [14, 15]. Various models describing the process leading to colon cancer begin with an initiating event, such as inherited or somatic mutations in the adenomatous polyposis coli (Apc) tumor suppressor gene. If these initiated precancerous cells $\left(\mathrm{Apc}^{+/}\right)$survive, they proliferate during the promotional phase of carcinogenesis. During this phase further genetic damage can be incurred, such as mutations in the p53 or deleted in colon cancer (DCC) genes [16]. In inflammation-associated colorectal cancer, such as cases associated with IBD, non-genetic stimuli also encourage the survival and proliferation of initiated cells [15]. 
Excess adipose tissue in specific anatomical locations may produce promotional adipokines that interact with hormones (e.g., insulin) and growth factors (e.g., insulin-like growth factors) that can act on initiated colon epithelial cells and increase colon cancer risk associated with the obese state.

It is noteworthy that loss of central adipose tissue or enhancement of subcutaneous adipose tissue reverses the negative metabolic syndrome profile characteristics associated with central adiposity $[17,18]$. These data suggest that adiponectin from subcutaneous white adipose tissue can negate the effects of pathophysiologic mediators originating from central adipose or omental adipose tissue. Leptin, interleukin-6 (IL-6) and adiponectin play direct roles in a variety of inflammatory situations both in vivo and in vitro. While all of these hormones/cytokines are critical to normal cell functioning at homeostatic concentrations, when levels are altered from normal (as in obesity) they may become pathologic. There is strong biological plausibility that an imbalance in these systemic mediators is causally related to obesity-associated cancers like colorectal cancer. The imbalance in these systemic mediators is thought to be involved in obesity-associated cancers. Exactly how this may happen mechanistically is not understood but is thought to be related to elevated systemic mediators of inflammation released by adipocytes, specifically, increased leptin, IL-6 and decreased adiponectin.

In this article we review the molecular mechanisms that may link obesity and cancer risk. We highlight adipokine research in prostate, breast, and intestinal dysplastic cells with special emphasis on colon epithelial cell lines that have yielded important information on early phenotypic events that may have relevance to colon carcinogenesis [19-25]. We use data generated from this model to propose a biologically plausible mechanism of obesity-associated cancer risk.

\section{ADIPOKINES: A REVIEW}

Historically, adipose tissue was primarily considered an organ used to store energy in the form of triacylglycerols, with secondary functions of insulation and shock absorption. However, within the last several years, adipose tissue is recognized as a functional endocrine organ with the ability to secrete a number of cell-signaling peptides called adipokines. These adipokines act both locally and distally in tissues, and have effects on a large number of bodily functions. These include lipid metabolism, inflammation, atherosclerosis, insulin resistance, reproduction, vascular homeostasis, food intake, thermoregulation, angiogenesis and immune function [26]. Unlike other secretory organs, adipose tissue is located throughout the body, with the contributions of metabolic secretions depending upon the location and size of the adipose tissue [27]. Furthermore, because fat cells have the ability to "network" with other tissues and organs such as skeletal muscle and the brain via hormone circulation and sympathetic nervous system activation, adipose tissue is highly integrated into overall metabolism and physiological processes of the body [28]. Adipocyte size and microenvironment may affect the cadre of adipokines secreted by adipocytes.
Intra-abdominal adipose tissue appears to produce many of the adipokines in amounts greater than that of fat deposits elsewhere in the body, causing android obesity to be both a symptom of and a diagnostic indicator for MS [29]. Metabolic syndrome in turn is a risk factor for the deve-lopment of cardiovascular disease, diabetes mellitus, peripheral vascular disease and stroke. Multiple studies have also found circulating adipokines to be contributing factors for increased risk of many types of cancer, including cancers of the breast, colon, kidney and esophagus [30]. The influence of adipokines on insulin sensitivity, glucose metabolism, inflammation and atherosclerosis may provide the molecular link between increased adiposity and development of obesity-related cancers [31]. Production and excretion of several adipokines and other adipose tissue-related hormones, including visfatin, omentin, resistin, insulin, leptin, interleukin- 6 and adiponectin, are significantly altered in obesity [32].

Several of these are pro-inflammatory cytokines that are released from adipose tissue even in the absence of acute injury or inflammation, supporting the characterization of obesity as a disorder of chronic mild inflammation. Significant evidence indicates that these adipokines are associated with the etiology of atherogenesis $[33,34]$. This review will focus on the role of adipokines in the process of carcinogenesis.

\section{Insulin and Cancer Risk}

Insulin is a hormone produced and release by the pancreas and is therefore not an adipokine by definition; however, obesity is known to cause insulin resistance, thereby leading to an increase in serum levels of insulin as a compensatory response to the resistance [35]. As such, insulin is included as a hormone that is markedly increased in conditions of obesity. Chronic hyperinsulinemia and insulin resistance increases risk for many types of cancer. It is unclear whether this risk is due to due to the direct effect of insulin on cell proliferation or the indirect effect of IGF and other hormones [36]. Aside from its role in the metabolism of glucose, insulin also increases serum levels of the structurally similar but more potent IGF, thereby acting indirectly through the IGF/IGFR system that is present on most cells throughout the body, which may also explain in part the relationship between obesity-related hyperinsulinemia and cancer risk [37]. When functioning normally, a signal transduced through the IGF receptor leads to activation of several intracellular pathways to maintain cell growth and survival, and these pathways are tightly controlled. In cancerous cells, however, IGF receptor activation may lead to neoplastic transformation, inhibition of apoptosis, metastasis and angiogenesis, all of which are cell alterations conducive to the development of tumors [38]. Downstream targets of IGF receptor comprise a signaling network that regulates cell growth, proliferation, survival and metabolism via energy availability and supply of growth factor [36].

Increased expression of IGF/IGFR was observed in cancers of the breast, colon, stomach, pancreas, liver, lung, thyroid and ovaries [39]. Although the exact role of IGF in the disease progression of some cancers (e.g. breast, 
prostate) remains controversial, multiple studies have found that higher levels of IGF are predictive of both stage and risk of metastasis for several types of tumors, including colorectal, gastric, liver, lung and gallbladder [40-44]. As a whole, these studies suggest the significance of IGF/IGFR expression as a possible indicator of tumor progression and outcome, although the data varies somewhat between specific types of cancers.

\section{Leptin and Cancer Risk}

Leptin, a product of the ob gene, was discovered as a hypothalamic regulator of body weight and energy balance by promoting a sensation of satiety upon adequate nourishment [45]. Mice with mutations in the gene encoding leptin become morbidly obese, infertile, hyperphagic, hypothermic and diabetic. The mice develop an insatiable appetite caused by a lack of leptin production [46, 47]. Although leptin may also be secreted from other sources, such as gastric mucosa and mammary epithelia, plasma concentrations of leptin are primarily influenced by adipose tissue stores [48]. Increased concentrations of leptin in obese individuals is associated with both greater amounts of adipose tissue as well as increased leptin release from adipocytes, these levels are higher in women than in men, and synthesis of leptin correlates with the presence of other hormonal factors, including insulin.

The association between leptin and cancer risk is a multifaceted relationship; leptin affects several tumorigenic pathways. Leptin may play a role in vascular remodeling via angiogenesis, both by itself and coupled with vascular endothelial growth factor (VEGF) and fibroblast growth factor (FGF), a necessary trait in the survival of tumors [49]. Leptin also increases endothelial cell hyperplasia and suppresses apoptosis, both of which are contributing factors in tumorigenesis [50]. The stimulation of several types of pre-neoplastic and neoplastic cells in vitro and in animal models appears to promote angiogenesis and tumor invasion [22]. Leptin plays more specific roles in vitro depending on the location of the cancer and type of tumors: increased cell proliferation is associated with leptin in cancers of the breast, prostate, ovary and lung; suppression of apoptosis by leptin is seen in colorectal and prostate cancer; and, increased pathway activation (e.g. ERK, STAT, PKC- $\alpha$ ) in breast, colorectal, pancreatic, ovarian and lung cancers [48]. Because leptin can be secreted by both adipose tissue as well as tumors themselves, local concentrations of leptin are crucial for tumor development, and may prove to become a useful target for inhibition in cancer treatment and prevention.

\section{Interleukin-6 and Cancer Risk}

Interlukin-6 (IL-6) is a cytokine that is produced by many tissues in the body, including muscle and adipose tissue, thereby also being classified as an adipokine. Previous studies have demonstrated that IL-6 is secreted by subcutaneous adipose tissue and is therefore to trigger systemic effects, particularly in obese subjects [51]. IL-6 is also secreted from perivascular adipose tissue, which can decrease protective vasodilatation of small arteries in obese subjects [52]. Adipose tissue contributes up to $35 \%$ of circulating levels of IL-6, leading to systemic effects as well as tissue-specific pleiotropic functions [53]. One of these effects is an increase in serum C-reactive protein (CRP), a blood protein released in response to inflammation, serving as a further indication that obesity is a disease of chronic inflammation. Park et al. found that IL-6 and CRP concentrations are significantly correlated with weight, BMI, waist/hip circumference and waist/hip ratio [54]. In addition, IL-6 has direct central actions, as evidenced by the discovery of IL-6 receptors on the hypothalamus, making IL-6 a possible vehicle of information transfer from adipocytes to the hypothalamus with respect to regulation of energy balance [32].

The mechanism of action for IL- 6 begins with binding of the molecule to a hexametric receptor that includes an IL-6 receptor and a signal transducer; the attachment of IL-6 and its receptor causes phosphorylation of STAT3 proteins that directly bind to target genes, affecting translation. The link between IL-6 and cancer tumorigenesis involves the activation of this pathway [55-57]. A previous study of IL-6 and its implications specifically for colon cancer concluded that tumor-infiltrating macrophages have the ability to release IL-6, increasing levels of intratumor IL-6 that condition the cancer cells to secrete IL- 6 themselves, thereby perpetuating a favorable environment for tumor growth and infiltration [58]. IL-6 has also been implicated in several other types of cancer; elevated serum IL-6 levels were found in patients with advanced stage or metastatic cancers of the breast, gastrointestinal tract, lymph nodes, lung, skin, ovary, pancreas, prostate and kidney [59-68].

\section{Adiponectin and Cancer Risk}

Adiponectin is an adipocyte-derived hormone with diverse biological functions including stimulation of glucose utilization, fatty-acid oxidation and inhibition of gluconeogenesis [69]. Serum levels of adiponectin exceed $10 \mu \mathrm{g} / \mathrm{ml}$, representing $\sim 0.01 \%$ of serum protein, in normal weight individuals [71]. Adiponectin self-associates in serum into at least three oligomeric complexes, including trimer, hexamer and octadecamer ("high molecular weight"; HMW) forms [71]. HMW forms of adiponectin predominate in serum of healthy human subjects; humans with diabetes and metabolic syndrome have a low percentage of HMW adiponectin relative to total adiponectin [72]. However, as obesity increases, adiponectin levels decrease and this decrease is thought to be associated with an increased risk of diabetes and cardiovascular disease, implying an early role for adiponectin in disease development [73]. Notably, weight loss in obese humans is associated with an increase in HMW adiponectin secretion.

Adiponectin also functions as an anti-inflammatory hormone by suppressing the migration of inflammatory mediators, such as monocytes and macrophages, to inhibit inflammation [74]. Adiponectin reduces plasma concentrations of triglycerides and fatty acids while increasing expression of proteins necessary for lipid metabolism, leading to an overall improvement of fatty acid catabolism, particularly in skeletal muscles [75]. Adiponectin increases insulin sensitivity, possibly as a result of its roles in increased lipid oxidation, improvement of insulin signaling, 
inhibition of gluconeogenesis, or inhibition of TNF- $\alpha$ [74]. The combination of increased insulin sensitivity and improved lipid catabolism indicates that adiponectin has a strong effect on regulation of energy balance and body weight, similar to that of leptin. Although most other adipokines, including leptin, are upregulated and found in increased circulating levels in obesity, adiponectin expression and concentration is markedly reduced in overweight and obese subjects [76]. Therefore, the diminished synthesis of adiponectin as a result of obesity may lead to dysregulation of the production of pro-inflammatory cytokines, thereby leading to increased insulin resistance and inflammation [74]. A negative correlation between circulating levels of adiponectin and obesity (particularly android obesity), as well as insulin resistance and type 2 diabetes is well established [77].

High circulating levels of adiponectin have several protective effects against the development of cancer. Adiponectin negatively regulates hematopoiesis, down regulates immune system response, induces apoptosis in certain cancer cell lines in vitro, and modulates expression of apoptosis-related genes [78]. Adiponectin has an anti proliferative effect by binding several mitogenic growth factors, inhibiting superoxide production, and negatively regulating angiogenesis [79-81]. Given these protective effects, there are also strong indications that decreased adiponectin may have a causal role in the development of several types of cancer. Adiponectin levels in vivo are inversely associated with increased risk of cancers associated with obesity and insulin resistance, including cancers of the endometrium, breast (particularly post-menopausal), colon, stomach and prostate, as well as leukemia [77]. This may be due in part to the relationship between adiponectin and insulin. Hyperinsulinemia associated with decreased adiponectin may lead to an increase in circulating IGF1, which in turn promotes cellular proliferation, inhibition of apoptosis and increased secretion of VEGF, all of which contribute to tumorigenesis [4].

\section{Molecular Mechanisms of Obesity and Breast Cancer Risk}

Adiposity is associated with elevated serum and plasma levels of certain compounds that seem to modulate important signaling pathways in mammary tumorigenesis. One interaction involves interplay between estrogen, insulin, and IGF-1. Obese post menopausal women have an increased risk of developing breast cancer in comparison to lean post menopausal women [82]. The primary site of estrogen biosynthesis in post-menopausal women occurs in adipose tissue of the breast, thighs, and buttocks. Circulating estrogen levels in these women increases with BMI, supporting the hypothesis that adipocyte-derived estrogen may be a factor in breast cancer risk [82]. Recent animal studies further this assertion. Obese ovariectomized C57BL/6 mice had increased mammary tumor growth in comparison with lean ovariectomized mice. Mammary tumors were also more prominent in obese mice regardless of ovarian hormone status, illustrating the general adverse role of obesity in breast cancer risk [83].
Current studies suggest that stimulation of the estrogen receptor (ER-alpha) is one of several mitogenic signals in breast epithelial cells [84]. As estradiol is an obvious ligand of the ER receptor, a second mechanism whereby IGF-1 both induces ER transcription and binds to the receptor itself may be equally as important. In fact, binding of ER by estradiol and IGF-1 produced more pronounced cell proliferation than the observed effect of each ligand alone [85]. The synergy between IGF-1 and estrogen is further demonstrated in vitro in both MCF-7 and T47D breast cancer cells [86]. Recent studies draw attention to the IGF-1 receptor as another crucial point of study. IGF-1R is over expressed in breast cancer cells and is associated with poor prognosis [87]. Activation of IGF-IR results in a chain of events that leads to inhibition of apoptosis and cell proliferation [88]. Interestingly, research demonstrates that estradiol can activate IGF$1 \mathrm{R}$, indicating that IGF-1/estrogen synergy is observed at the level of IGF-1R as well as ER. Elevated serum levels of both IGF-1 and insulin increase breast cancer risk [89, 90]. Insulin increases estradiol levels by inducing aromatase expression in adipose tissue [91]. These data suggests that hyperinsulemia, a common consequence of obesity, and endocrine activity of adipocyte-derived estrogen produce a cascade of events leading to dysregulation of the cell cycle and subsequent acceleration of cell proliferation.

Leptin may also contribute to an elevated risk of breast cancer in obese individuals. Leptin expression is found in human breast cancer lines and mammary tumors [92, 93]. However leptin receptors are much more prominent in tumor cells than in normal breast tissue [94]. The importance of the leptin receptor is supported in several animal models. Obese Zucker rats, which express a dysfunctional leptin receptor, developed mammary carcinoma only $10 \%$ of the time when exposed to a chemical carcinogen in contrast to $50 \%$ of their lean counterparts [95]. In addition, MMTV-TGF- $\alpha /$ Lepr $^{d b}$ $L_{e p r^{d b}}$ mice have mutated leptin receptors and overexpress the oncogene TNF-alpha but do not develop mammary tumors $[96,97]$. This suggests that leptin signaling in the presence of excess adipose tissue is pertinent to mammary tumor development. The underlying mechanism of leptin signaling appears to involve the ER receptor. Like insulin, leptin induces the synthesis of estradiol via upregulation of aromatase activity but can also directly activate the receptor in the absence of its usual ligand in MCF-7 cells [98][99]. Leptin also acts to increase MCF-7 cell proliferation via multiple mechanisms including regulating the cell cycle, apoptosis, and by modulating the extracellular environment [100]. Leptin may collaborate with IGF-1 to promote cell proliferation through activation of ER and subsequent stimulation of PPAR-alpha and PPAR-gamma [101,102].

Adiponectin reduces cell proliferation and induces apoptosis in both estrogen-sensitive and estrogen-insensitive human breast cancer cells $[103,105]$. This growth-inhibitory activity may be due to adiponectin-induced expression of certain apoptotic genes [105]. Adiponectin also attenuates mammary tumor development in vivo [104]. Breast tumors induced in adiponectin (APN) null transgenic mice using the polyoma virus middle $\mathrm{T}$ oncogene showed increased frequency of pulmonary metastases. Tumor analyses indicated reduced vascularization of APN null tumors along with increased hypoxia and apoptosis $[106,107]$. 


\section{Molecular Mechanisms of Obesity and Prostate Cancer Risk}

While several studies report positive associations between increased adiposity and prostate cancer risk, sparse investigation has resulted in an ambiguous understanding of possible biochemical links. Obesity is positively associated with metabolic syndrome, a condition characterized by elevated levels of insulin, IGFs and cytokines. These three factors acting alone or in concert are thought to increase the risk of developing high-grade prostate cancer [108]. Tokuda et al demonstrated that prostate cancer cells cultured in the presence of adipocytes displayed abnormal differentiation and increased cytokine production [109]. These results indicate that adipocytes may secrete compounds that act in a paracrine manner to promote carcinogenesis in nearby prostate cells. As in breast cancer, the development of prostate cancer seems to be correlated with hormones and signaling molecules that are also implicated in obesity. These biological compounds include testosterone and the adipokines, leptin, interleukin-6 and adiponectin.

Serum testosterone levels are generally depressed in obese individuals $[108,110]$. This observation is likely due in part to increased conversion of androgens to estrogen via aromatase activity within the adipocytes. Thus the presence of excess adipose tissue creates imbalanced levels of circulating androgens. Decreased testosterone may place obese males at a reduced risk of developing prostate cancer because androgens are potent inducers of differentiation in prostate cells [111]. However, current research suggests the interplay between androgens and prostate tumor cells varies with origin and severity. High levels of testosterone are associated with a reduced risk of developing high grade dysplastic prostate tumors but an increased risk of low grade tumors [112]. Furthermore, obese individuals seem to have a reduced risk of exhibiting low grade prostate tumors but a much greater risk of developing aggressive tumors [113, 114]. However, it is likely that multiple variables including hereditary and age of onset influence androgen dependence of prostate cancer cells [108].

Numerous studies assert that leptin and IL-6 may also play key roles in the link between obesity and prostate cancer. Leptin has been found to induce cell migration, enhance anti-apoptotic activity and expression of growth factors such as vascular endothelial growth factor (VEGF) and tumor necrosis factor (TNF)-beta-1 in human prostate cancer cells $[115,116]$. Further investigation indicates that mitogenic effects of leptin may be produced via the phosphoinositide-3 kinase (PI3K) and MAPK pathways [117]. Leptin also has a more pronounced proliferative effect on androgen-independent prostate cancer cells in comparison to cells that are androgen-dependent [118]. This finding is especially relevant with regards to obesity because as previously stated, obese males are at greater risk of developing cases of prostate cancer that are androgen-insensitive.

In addition to leptin, multiple in vitro and in vivo models have demonstrated mitogenic qualities of the proinflammatory cytokine, IL-6. In LNCaP and MDA PCa 2b prostate cancer cells, IL- 6 potentiates cell proliferation [119, 120]. When mice were inoculated with $\mathrm{LNCaP}$ cells and exposed to IL-6, accelerated tumor growth was observed in comparison to mice that were inoculated with cells free of
IL-6 exposure. These results were attributed to activation of the MAPK pathway [121]. Transgenic murine prostate cancer model (TRAMP) mice spontaneously develop prostate adenocarcinoma, have greater body fat composition and increased incidence of prostate tumors in addition to increased serum levels of leptin and decreased levels of adiponectin [122]. Obese TRAMP mice fed a high-fat diet exhibited more pronounced androgen-independent cell proliferation than lean mice fed a normal diet [123]. The study also established that greater doses of leptin administered to genetically obese leptin deficient mice were associated with enhanced stimulation of androgen-independent proliferation.

As in breast cancer, adiponectin may play a protective role in prostate cancer. It is not surprising that patients with prostate cancer exhibit decreased serum levels of adiponectin [124]. Adiponectin reduces cell proliferation in both androgen dependent and androgen independent prostate cancer cell lines $[125,126]$. Studies aimed to elucidate the mechanism by which adiponectin modulates tumorigenesis in the prostate have drawn inconclusive results.

\section{Molecular Mechanisms of Colon Cancer and Obesity}

Excess adipose tissue can influence colonic dysplasia on several planes. As in breast and prostate cancer, adipokines such as IL-6, leptin, and adiponectin modulate tumorigenesis in multiple models of colon cancer. Carcinogenic colon epithelial cells cultured in the presence of adipocytes experience increased proliferation [127]. This outcome supports the hypothesis that adipokines secreted from adipose tissue directly influence tumorigenesis in a paracrine fashion.

A concrete body of evidence illustrates the role of leptin in colon cancer. Leptin is positively associated with increased risk of inflammation-induced colon cancer in mice [128]. In addition, the leptin receptor is over expressed in colon cancer cells [45]. Leptin stimulates proliferation and anti-apoptotic activity in HT-29, Caco-2 and T-84 colon cancer cell lines [129-131]. Leptin may also exacerbate inflammatory response in colon cancer cells [132]. However leptin has no effect on colon epithelial proliferation in normal rats [133]. This indicates that adipocyte-derived leptin is more active in modulating pro-carcinogenic activity after epithelial cell differentiation. Leptin-mediated cell survival is produced by nuclear penetration of NFkB [134]. Investigations have also revealed that the mechanism of leptin signaling may involve activation of the JAK/STAT pathway and the Rho family of GTPases [130, 135].

Obesity is associated with an elevated state of chronic low grade inflammation. Increased production of the proinflammatory cytokine, IL-6, appears to positively regulate cell proliferation and inhibit apoptosis of premalignant intestinal epithelial cells [136]. Decreased levels of serum IL-6 are associated with the reduction of colon cancer in obese rats [137]. In addition, IL-6 seems to be required for maintenance of inflammation and prevents the cell from protecting itself by inhibiting entrance into oncogeneinduced senescence [138]. Thus, individuals with increased inflammation as in obesity will have increased production of IL-6 and greater subsequent risk of tumor development. 
As in breast and prostate cancer, reduced adiponectin levels in obese individuals may increase cancer risk. Adiponectin reduces cell proliferation in mice fed a high fat diet via inhibition of the rampamycin pathway [139]. On the contrary, adiponectin increased proliferation and cytokine production in HT-29 colon cancer cells through upregulated nuclear translocation of $\mathrm{NF \kappa B}$. The role of adiponectin in colitis-associated colon cancer is controversial. Adiponectin is protective in rats with DSS-induced colitis [140]. However, conflicting studies have shown that adiponectin does not protect against colitis in the same model [141, 142]. Adiponectin may work to block leptin-induced signaling pathways in colon epithelial cells [20]. Leptin does not seem to influence normal colon epithelial cells [23]. Thus if leptin signaling is only relevant in preneoplastic or neoplastic cells, the proposed mechanism whereby adiponectin blocks leptin signaling would not be expected in models of colitis where little differentiation has occurred.

\section{OVERVIEW OF COLON EPITHELIAL CELL (CEC) MODELS: AN ILLUSTRATIVE EXAMPLE}

Our laboratory has utilized several cell lines to unravel molecular mechanisms that may underlie obesity and cancer risk. These model cell lines are described below. Fig. (1) depicts these cell lines diagrammatically in the context of increasing neoplastic potential.

\section{Cell Lines}

This model system consists of murine colon epithelial cell lines that can mimic a variety of genetic mutation in cells that can represent stages of carcinogenesis. Conditionally immortal cell lines were developed in the early 1990's from the transgenic mouse (Immorto mouse) bearing a temperature-sensitive mutation of the simian virus 40 large tumor antigen gene (tsA58) which was placed under the control of the gamma interferon inducible $\mathrm{H}-2 \mathrm{~Kb}$ promoter (H-2Kb-tsA58)[143]. Colonic crypts were isolated from the Immorto mouse and YAMC $\left(A p c^{+/+}\right)$cells were collected as described [144]. The IMCE $\left(A p c^{\mathrm{Min} /+}\right)$ colonic epithelial cell line was derived from an F1 hybrid between the SV 40 large
$\mathrm{T}$ antigen transgenic mouse (Immorto mouse) and the $A p c^{\mathrm{Min} /+}$ mouse [145]. The first cell line mimics normal colon epithelial cells [Young Adult Mouse Colon cells or YAMC $\left.\left(A p c^{+/+}\right)\right]$and a cell line with a mutation in the $A p c$ tumor suppressor gene [Immorto-Min Colonic Epithelium cells or IMCE $\left.\left(A p c^{\mathrm{Min} /+}\right)\right]$ that mimics preneoplastic colon epithelial cells. This mutation in the $A p c$ gene is very relevant to colon cancer research as it is considered one of the earliest events in the initiation and progression of colorectal cancer [146]. Min mice develop intestinal adenomas similar to FAP patients 147]. There are numerous phenotypic changes in the IMCE $\left(A p c^{\mathrm{Min} /+}\right)$ cells that are consistent with the hypothesis that decreased wild-type $A p c$ expression is associated with colorectal carcinogenesis including reduced growth-factorinduced migration, reduced connexin-mediated cell-cell communication and increased inducible nitric oxide synthase (iNOS) and cyclooxygenase-2 (COX-2) expression [16, 21, 145, 148]. These preneoplastic phenotypes are consistent with known early phenotypes in human colorectal cancer. In $A p c^{\mathrm{Min} /+}$ mice, a heterozygous mutation in $A p c$ is sufficient to reduce microtubule polymerization and $\mathrm{Cx} 43$ expression in intestinal epithelial cell lines [149]. These data suggest that the progressive loss of wild-type Apc in colorectal carcinogenesis is associated with the acquisition of growth promoting and apoptosis inhibitory capabilities that promote neoplasia.

In addition, the group that derived these two cell lines infected the YAMC and IMCE cell lines with a replicationdefective psi2-v-Ha-ras virus and derived cell lines which over express the v-Ha-ras gene (YAMC-Ras and IMCERas). The IMCE-Ras cells are able to grow in soft agar and form tumors in nude mice within 3 weeks and YAMC-Ras cells form tumors after 90 days. The phenotype of the IMCE-Ras cell line thus clearly demonstrates that a defective Apc allele and an activated ras gene are sufficient to transform normal colonic epithelial cells and render them with varying tumorgenicity [150].

Other relevant pathways that are mutated in the development of colon cancer include the TGF- $\beta$ pathway $[151,152]$. Similarly, conditionally immortal colon epithelial cells are available that carry a mutation in the Smad3 transcription factor (153). The Smad3 -/- colon epithelial

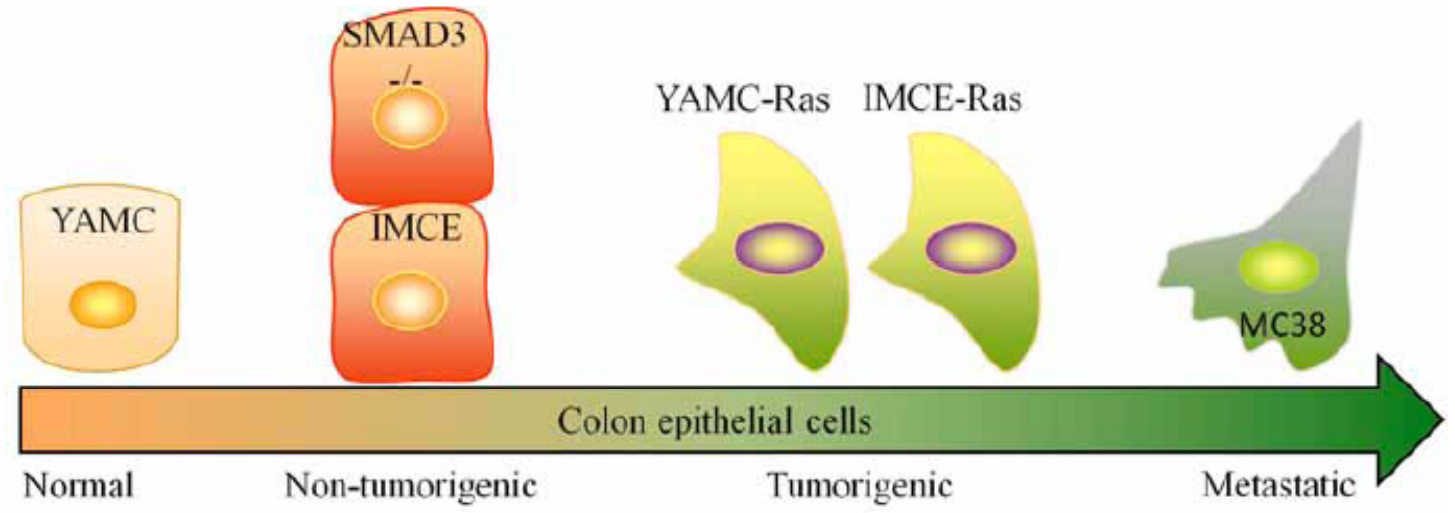

Fig. (1). Continuum of murine colon epithelial cells available for modeling molecular mechanisms of colon cancer risk. The cells to the left represent model normal colon epithelial cells (YAMC) and progress to the right with increasing mutations culminating in an adenocarcinoma cell line (MC-38). The IMCE cells carry one truncated copy of the tumor suppressor gene Apc (gatekeeper mutation in colon cancer). The SMAD cells are null for the transcription factor SMAD3, involved in TGF-beta signaling. The YAMC/IMCE-Ras cells over express Ras. All the mutations are relevant to the process of colon carcinogenesis. 
cell line was derived by crossing Smad3 -/- mice with the immortomouse [153]. SMAD3 is a transcription factor that is critical to transforming growth factor (TGF)- $\beta$. The phosphorylated type I receptor itself phosphorylates complexes SMAD2, SMAD3 and SMAD4 which accumulate in the nucleus, acting as transcription factors for the regulation of specific gene expression in the cell. As opposed to homozygous SMAD2 or SMAD4 mice, homozygous SMAD3 -/knockout mice were found to be viable, but when exposed to a pathogen these mice develop colitis and colon adenocarcinomas [154]. TGF- $\beta$ is an important signaling pathway in the process of tumorigenesis because it controls prolixferation, differentiation, apoptosis, homeostasis and other functions of cells [155].

Finally, the syngenic murine colon adenocarcinoma cell line (MC38) is also available to compare the responses of nontumorigenic cells with varying mutations to normal and adenocarcinoma cell lines. The murine carcinoma-38 (MC38) colon cancer cell line was derived from a murine colon tumor, grade III carcinoma, which was chemically induced in the $\mathrm{C} 57 \mathrm{Bl} / 6$ female mouse $[156,157]$.

\section{Properties of the Cells}

YAMC $\left(A p c^{+/+}\right)$and IMCE $\left(A p c^{\mathrm{Min} /+}\right)$ cell lines display epithelial morphology: they express keratin-18 (an epithelial cell specific protein), growth in culture is contact inhibited, and they die over 7 days [143-145]. In addition, these cell lines are non-tumorigenic in nude mice, do not grow in soft agar and survive in culture only on extracellular matrix proteins such as collagen I [145]. The cells are grown on 75 $\mathrm{cm}^{2}$ culture flasks coated with $5 \mu \mathrm{g} / \mathrm{cm}^{2}$ type I collagen in RPMI 1640 media supplemented with 5\% neonatal calf serum, insulin/transferrin/selenium (ITS), $5 \mathrm{IU} / \mathrm{ml}$ of murine IFN- $\gamma$, and $100000 \mathrm{IU} / 1$ penicillin and $100 \mathrm{mg} / 1$ streptomycin with $5 \% \mathrm{CO} 2$. As described above, both YAMC $\left(A p c^{+/+}\right)$and IMCE $\left(A p c^{\mathrm{Min} /+}\right)$ cells express the heat-labile SV40 large $\mathrm{T}$ antigen under the control of an IFN- $\gamma$ inducible promoter. At $33^{\circ} \mathrm{C}$ with IFN- $\gamma$ present in the media, the temperature-sensitive SV40 large $\mathrm{T}$ antigen is active, binds to and inactivates p53 and drives cell prolixferation. At $39^{\circ} \mathrm{C}$ the temperature-sensitive mutation yields an inactive protein, and the cells behave as non-proliferating, differentiated colonic epithelial cells. Under these nonpermissive conditions, the cell lines behave like normal cells in that they are contact inhibited and undergo apoptosis if they achieve maximal confluence. Therefore, conditions are optimized for cells to proliferate slowly for $24 \mathrm{~h}$ at $39^{\circ} \mathrm{C}$ and then undergo cell death over 5-8 days, similar to the lifecycle of a normal colonic epithelial cell. When the cell lines are transfected with v-Ha-ras, IMCE $\left(A p c^{\mathrm{Min} /+}\right)$ cells are able to grow in soft agar and form tumors in nude mice within 3 weeks and YAMC $\left(A p c^{+/+}\right)$cells form tumors after 90 days [150].

\section{USING CEC'S TO STUDY OBESITY AND COLON CARCINOGENESIS}

\section{Leptin and Cell Proliferation}

Our laboratory has used these cell lines as models to understand the role adipokines and colon cancer risk. At the outset of this research question we assessed the effects of leptin, IGF-1 and IGF-2 on colonic epithelial cell homeostasis using a range of physiologically relevant concentrations of these growth factors associated with human metabolic syndrome. We identified a differential effect of leptin on cell proliferation and apoptotic potential between two non-tumorigenic epithelial cells with distinct $A p c$ genotypes. Given the "gatekeeper" role of this important protein in colon carcinogenesis, it is highly relevant that we identified a differential effect of leptin on cell proliferation and apoptotic potential in YAMC $\left(A p c^{+/+}\right)$colonic epithelial cells and IMCE $\left(A p c^{\mathrm{Min} /+}\right)$ colonic epithelial cell lines, both of which are non-tumorigenic. We showed that leptin reduced cell proliferation in YAMC $\left(A p c^{+/ t}\right)$ cells and that this effect was associated with an induction of caspase activity and apoptosis. In contrast, leptin, IGF-1, and IGF-2 induced cell proliferation in colonic epithelial cells possessing one truncated copy of $A p c$ [IMCE $\left.\left(A p c^{\mathrm{Min} /+}\right)\right]$ ]. IMCE $\left(A p c^{\mathrm{Min} /+}\right)$ cell proliferation was augmented when IMCE $\left(A p c^{\mathrm{Min} /+}\right)$ cells were treated with IGF-1 or IGF-2 in combination with leptin [22]. The differential proliferative responses to leptin in IMCE $\left(A p c^{\mathrm{Min} /+}\right)$ and YAMC $\left(A p c^{+/+}\right)$ cells cannot be explained by significant differences in relative abundance of the leptin receptor $(\mathrm{Ob}-\mathrm{R})$. We showed that leptin treatment of these cells induced phosphorylation of p42/44 MAPK and p38 MAPK and activation of NF- $\kappa$ B as evidenced by NF- $\kappa$ B nuclear accumulation [22].

\section{Leptin Induces Gene Expression Changes}

Microarray technology and pathway analysis revealed that the most upregulated genes in the IMCE $\left(A p c^{\mathrm{Min} /+}\right)$ cells treated with leptin were cell cycle and proliferation genes, whereas the most upregulated genes in the leptin-treated YAMC $\left(A p c^{+/+}\right)$cells were primarily genes involved in the regulation of cell maintenance/homeostasis and genes related to apoptosis [25]. Leptin induced changes in gene expression in IMCE $\left(A p c^{M i n /+}\right)$ cells in cell signaling pathways involved in cell proliferation, including calcium signaling, p53, Wnt, and IGF pathways that were not altered by leptin treatment of YAMC $\left(A p c^{+/+}\right)$cells. Genes regulating the $\mathrm{Wnt} / \mathrm{\beta}$ catenin-mediated pathway including Mdm2, Pik3r1, and Rb1 were upregulated by leptin. Importantly, leptin induced IGFmediated pathway gene expression changes and their protein products in IMCE $\left(A p c^{\mathrm{Min} /+}\right)$ cells. In the IMCE $\left(A p c^{\mathrm{Min} /+}\right)$ cells IGFBP-6, IGF-1, and Crim1 expression was upregulated, while IGFBP-2, IGFBP-3, IGFBP-4, IGFBP-5, and Nov expression was down regulated by leptin treatment. These pathways are consistent with those implicated in colon carcinogenesis.

\section{Leptin Induces Self Sustained Growth Signals}

We were motivated to identify a leptin-inducible factor responsible to explain this differential proliferative response of the two cell types. In another study we had queried the effect of leptin exposure on the production of proinflammatory signals on these cells [158]. We characterized the production of specific cytokines, $\mathrm{CC}$ and $\mathrm{CXC}$ chemokines by IMCE $\left(A p c^{\mathrm{Min} /+}\right)$ and YAMC cells using an antibodybased cytokine array. 
The cytokine IL-6 was increased in IMCE $\left(A p c^{\mathrm{Min} /+}\right)$ cells compared to YAMC $\left(A p c^{+/+}\right)$cells and when treated with leptin the production of IL-6 was increased in IMCE $\left(A p c^{\mathrm{Min} /+}\right)$ cells only. We established a time-dependent and concentration-dependent increase in IL-6 secretion after leptin treatment of IMCE $\left(A p c^{\mathrm{Min} /+}\right)$ cells (23). IL-6, as a prospective autocrine factor candidate, was concordant with observations that intestinal epithelial cells secrete IL-6 in response to inflammatory signals, such as those occurring in IBD $[159,160]$, and that IL-6 is involved in intestinal inflammation [161]. IL-6 treatment, in a concentrationdependent fashion, induced IMCE $\left(A p c^{\mathrm{Min} /+}\right)$ but not YAMC $\left(A p c^{+/+}\right)$cell proliferation. Consistent with IL-6 signaling, IL-6 treatment resulted in a time-dependent phosphorylation of ERK, MEK 1/2, p38, JAK2 and STAT3. The activation of these signaling proteins led to the phosphorylation of STAT3 and translocation of activated and functional STAT3 into the nucleus of IMCE $\left(A p c^{\mathrm{Min} /+}\right)$ cells. Upon further investigation, dramatic differences in IL-6 receptor complex regulation were observed between IMCE $\left(A p c^{\mathrm{Min} /+}\right)$ and YAMC $\left(A p c^{+/+}\right)$cells. Untreated YAMC $\left(A p c^{+/+}\right)$cells had more membrane bound IL-6R than IMCE $\left(A p c^{\mathrm{Min} /+}\right)$ cells. However, in response to leptin treatment IMCE $\left(A p c^{\mathrm{Min} /+}\right)$ cells shed soluble IL-6R into conditioned media, while the YAMC $\left(A p c^{+/+}\right)$cells did not. The gp130 membrane receptor was present on the membranes of both cell types. We observed some shedding of gp130 only in IMCE $\left(A p c^{\mathrm{Min} /+}\right)$ cells in response to leptin treatment. Leptin induced IL-6 production, IL-6R membrane shedding and trans-IL-6 signaling in IMCE $\left(A p c^{\mathrm{Min} /+}\right)$ colon epithelial cells [23].

\section{Leptin Induces Chemokine Production and Immune Cell Migration}

Further, since epithelial cells are hypothesized to be accessory to the inflammatory response [162], we assessed the ability of supernants from leptin-exposed colon epithelial cells to activate macrophage chemotaxis and nitric oxide production. Both YAMC $\left(A p c^{+/+}\right)$and IMCE $\left(A p c^{M i n /+}\right)$ cells produced the following chemokines from the $\mathrm{CC}$ family; MCP-1, MIP-3alpha, TCA-3, CTACK and RANTES. These cell lines also produced the following CXC chemokines; MIP-2, CXCL18, KC and LIX. We described the differential leptin-induced production of five $\mathrm{CC}$ chemokines and four $\mathrm{CXC}$ chemokines in colon epithelial cells contrasting in $A p c$ genotype using a novel protein array method [158]. Based on these results, it was logical to speculate on the specific phenotypes of immune cells activated by the pattern of chemokines produced. We surveyed two phenotypes of macrophage function: macrophage chemotaxis and macrophage nitric oxide production. Conditioned media from leptintreated YAMC $\left(A p c^{+/+}\right)$and IMCE $\left(A p c^{M i n /+}\right)$ cells induced nitric oxide production by macrophages. However, only conditioned media from leptin-treated IMCE cells induced macrophage chemotaxis $(\mathrm{P}<0.05)$. These data implied that preneoplastic but not normal cells may selectively attract immune cells that promote their survival and transformation.

\section{Leptin Induces VEGF Production and Capillary Formation}

Using the protein array technology, we also observed that VEGF production was increased by leptin treatment of
IMCE $\left(A p c^{\mathrm{Min} /+}\right)$ cells. It was previously unknown whether leptin could induce epithelial cells to produce factors that may drive angiogenesis, vascular development, and therefore cancer progression. Leptin treatment induced dose-dependent increases in VEGF only in IMCE cells. Conditioned media from leptin $(50 \mathrm{ng} / \mathrm{ml})$ treated IMCE $\left(A p c^{\mathrm{Min} /+}\right)$ cells induced significant capillary formation compared to control, which was blocked by the addition of a neutralizing antibody against VEGF (19). Conditioned media from leptin-treated IMCE $\left(A p c^{\mathrm{Min} /+}\right)$ cells also induced human umbilical endothelial cell (HUVEC) proliferation, chemotaxis, upregulation of adhesion proteins, and cell-signaling activation resulting in NFKB nuclear translocation and DNA binding due to VEGF [19]. This was the first study demonstrating that leptin could induce preneoplastic colon epithelial cells to orchestrate VEGF driven angiogenesis and vascular development.

\section{An Overarching Role for Adiponectin in Cell Number Homeostasis}

Low serum adiponectin is associated with colon, prostate and breast cancer. Adiponectin is secreted by white adipose tissue; the levels of adiponectin in the blood decrease as body mass index (and leptin) increases. Adiponectin is found in serum at very high concentrations representing $0.01 \%$ of serum protein, in normal weight individuals [70]. Adiponectin may influence cancer risk through its wellrecognized effects on insulin resistance. Certainly, elevated insulin and glucose intolerance are linked to colon cancer risk [163, 164]. However, adiponectin may act on tumor cells directly. One recent in vitro study implicated that adiponectin may control cancer cell growth. The authors treated MDA-MB-231 breast cancer cells with adiponectin and induced cell growth arrest and even apoptosis [165].

We tested whether murine recombinant globular adiponectin (gArcp30) could modulate leptin-induced cell proliferation, autocrine IL-6 production, trans-IL-6 signaling and other leptin-induced cell signaling events previously observed in IMCE $\left(A p c^{\mathrm{Min} /+}\right)$ cells but not YAMC $\left(A p c^{+/+}\right)$ cells. Physiologic amounts of adiponectin (under serum free conditions) inhibited leptin-induced cell proliferation. The reduction in cell proliferation was due to inhibition of the autocrine IL-6 production, soluble IL-6 receptor shedding, trans-IL-6 signaling and subsequent STAT3 phosphorylation in IMCE $\left(A p c^{\mathrm{Min} /+}\right)$ cells. In addition, adiponectin cotreatment with leptin in IMCE $\left(A p c^{\mathrm{Min} /+}\right)$ cells was associated with I kappa B-alpha phosphorylation, I kappa B-alpha degradation and decreased NFKB p65 DNA activation and binding. We hypothesize that adiponectin may be an important regulator of colon epithelial cell homeostasis by linking the observed reduced risk for cancer in populations with high serum adiponectin concentrations to specific mechanisms of cell number homeostasis in this model of preneoplastic colon epithelial cells.

\section{Summary}

Taken together, these data provide a rational basis for adipokine-induced cross-talk between preneoplastic epithelial cells and immune cells that may influence the promotional phase of carcinogenesis. In the spirit of 


\section{Proposed Model}

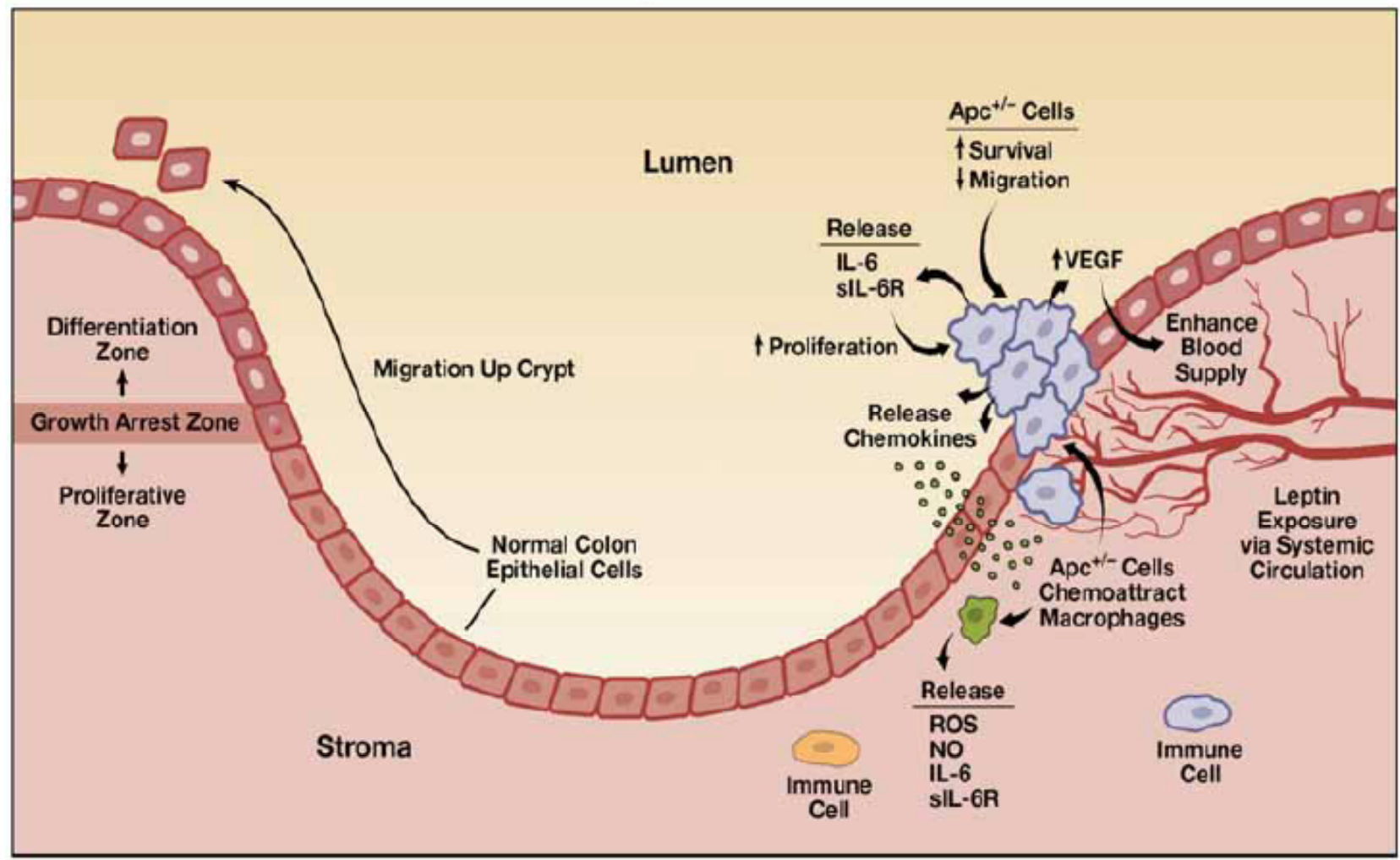

Fig. (2). Proposed model for leptin and colon cancer risk (19, 22, 23, 25, 158). Leptin exposure of IMCE (Apc +/-) cells induces a cascade of events that may explain increased cancer risk. Compared to normal colon epithelial cells, the IMCE cells are less motile and more resistant to apoptosis. Polyps tend to form at the growth arrest zone as shown in the figure. Upon exposure to leptin, colon epithelial cells carrying a mutation in Apc exhibit increased cell growth and proliferation, increased VEGF, and increased cytokine and chemokine production compared to normal cells. These promotional influences in IMCE cells result in cell number expansion, vascularization and immune cell chemoattraction to further promote carcinogenesis.

translational research approaches, extrapolation of these data to in vivo conditions may be hypothetically represented as in Fig. (2). The microenvironment of colon epithelial cells is exposed to elevated leptin via systemic circulation. If there are cells sitting in the microenvironment possessing a muta- tion, in $A p c$ for example, those cells would be susceptible to the proposed promotional influence of leptin. Exposure of these cells to elevated leptin would result in increased production of I1-6, VEGF, chemokines and other growth factors. These signals would result in the phenotypic conse-

\begin{tabular}{|c|c|c|}
\hline Hallmarks of Cancer (166) & $\begin{array}{l}\text { Evidence for phenotype } \\
\text { induced in leptin-treated } \\
\text { IMCE cells }\end{array}$ & $\begin{array}{l}\text { Phenotype induction by } \\
\text { leptin }\end{array}$ \\
\hline Evading Apoptosis & ++ & Cell Proliferation (22) \\
\hline $\begin{array}{l}\text { Self Sufficiency Growth } \\
\text { Signals }\end{array}$ & +++ & $\begin{array}{l}\text { Trans IL- } 6 \text { signaling ( } 23 \text { ) } \\
\text { Can induce immune cell } \\
\text { migration and activation( } 158)\end{array}$ \\
\hline $\begin{array}{l}\text { Insensitivity to Anti- } \\
\text { growth Signals }\end{array}$ & ++ & $\begin{array}{l}\text { Activation cell signaling } \\
\text { genes }(22,25)\end{array}$ \\
\hline Sustained Angiogenesis & +++ & VEGF production (19) \\
\hline $\begin{array}{l}\text { Limitless Replicative } \\
\text { Potential }\end{array}$ & + & $\begin{array}{l}\text { Activation of cell cycle } \\
\text { pathway genes }(25)\end{array}$ \\
\hline $\begin{array}{l}\text { Tissue Invasion and } \\
\text { Metastasis }\end{array}$ & - & $\begin{array}{l}\text { IMCE cell migration was not } \\
\text { induced by leptin } \\
\text { (unpublished data) }\end{array}$ \\
\hline
\end{tabular}

Fig. (3). Summary of "Hallmarks of Cancer" Phenotypes induced by leptin in the IMCE cells.

The Hallmarks of Cancer as defined by Hanahan and Weinburg are listed in the first column followed by levels of evidence and the corresponding phenotype published in the IMCE cells. 
quences of increased cell survival, cell proliferation, immune cell migration and activation, and angiogenesis. All these changes would support the promotion and survival of these cells so that the cell population would expand and survive to acquire further mutations enhancing carcinogenesis. These phenotypic changes induced in the IMCE $\left(A p c^{\mathrm{Min} /+}\right)$ cells are consistent with the necessary phenotypes acquired by cancer cells as described in "The Hallmarks of Cancer" paper [166] and are reviewed in Fig. (3).

\section{Stage Specific Effects of Adipokines (Unpublished Data)}

It is important to note that the genetic changes occurring in cells across the continuum from a normal to a neoplastic cell will influence the response of the cell to a given signal. Summarized above is the differential response of model normal (YAMC) and preneoplastic (IMCE) colon epithelial cells. However, we briefly discussed several other available colon epithelial cell lines with various other mutations including adenocarcinoma cells. The response of these other cell lines to adipokines may vary substantially and provide insight into changing promotional influences depending on the mutations. We treated the other cell lines with these adipokines and queried the effect on cell number homeostasis. The results for leptin and IL-6, forthcoming in subsequent publications, are summarized in Fig. (4) (unpublished data). Leptin and IL-6 both have clear stage-dependent effects of cell proliferation. Cell proliferation is driven by leptin in the "transformed cell lines" (IMCE and SMAD) but then has no effect on cell proliferation in the YAMC/IMCERas cell lines or the MC-38 cells and in fact reduces cell proliferation in the normal (YAMC) cell line. It appears that the overexpression of $\mathrm{v}$-Ha-ras gene in these cell lines is sufficient to drive cell growth and transformation independent of external signals [150]. The metastatic cell line MC38 did not respond to leptin, however the leptin receptor protein was not measurable in these cells by western blot. In the IMCE and SMAD cell lines the increase in cell proliferation by leptin is driven by consistent pathway activation of MAPK and NFKB (Fig. 5).

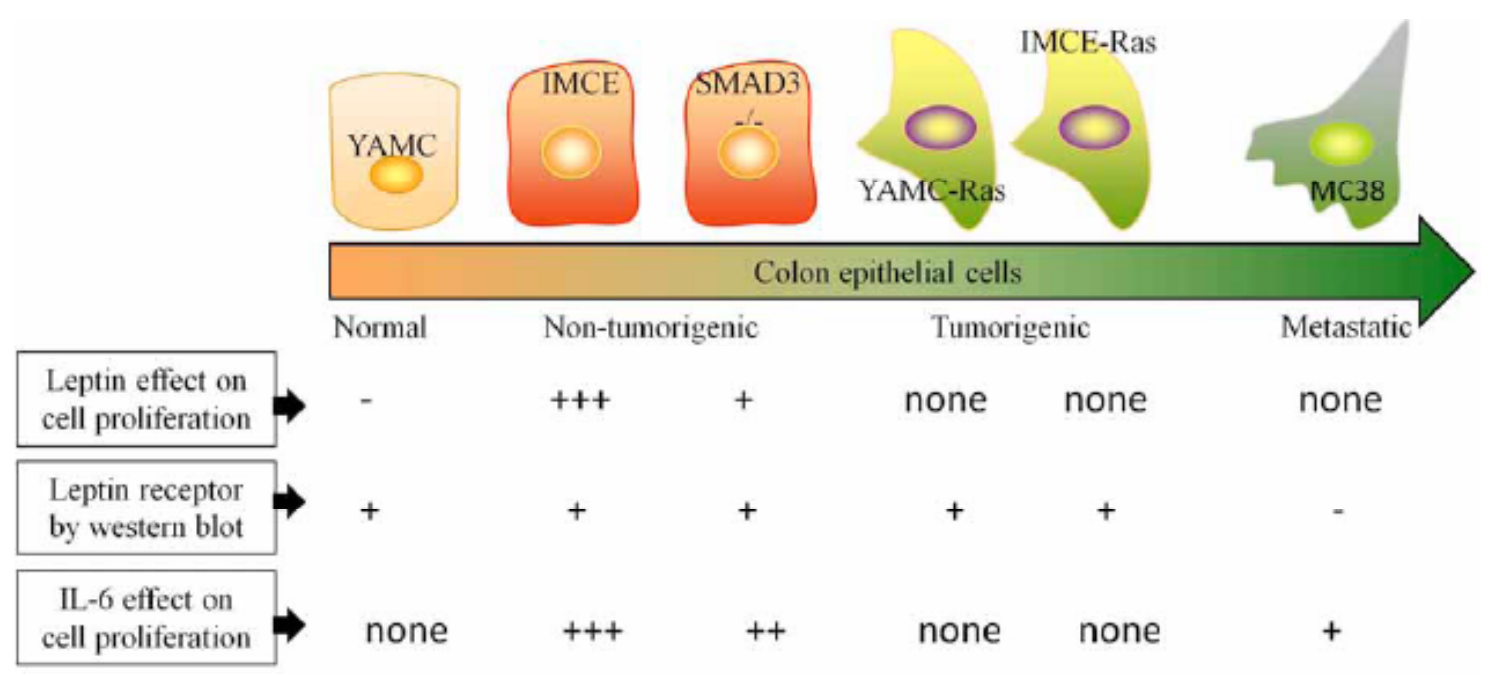

Fig. (4). Summary of stage-dependent differences in leptin receptor and cell response to leptin and IL-6 (unpublished data).

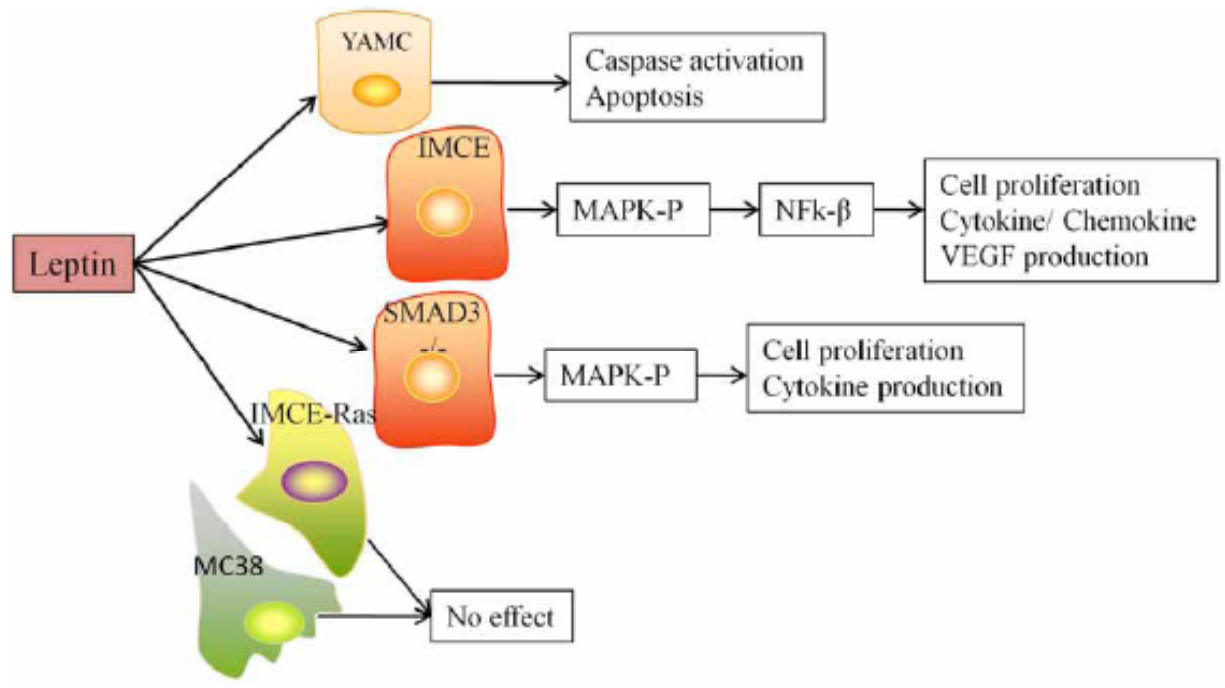

Fig. (5). The cell signaling response of colon epithelial cells to leptin depends on the stage [22, 23]. The response by cell type and phenotype is represented. 
In contrast to leptin, IL-6 drives cell proliferation in the MC38 late stage cells as well as the IMCE and SMAD cells (Fig. 4). Again, the v-Ha-ras transformed cell lines did not respond to treatment with IL-6. However, these data indicate the IL-6 may be a more non specific target and a key player for colon tumor promotion.

\section{SYNOPSIS}

The multistage nature of carcinogenesis and our advancing knowledge of the critical mechanisms involved at each stage provide strategies for the prevention of cancer. The use of models of this multistage process should allow for mechanism-based approaches to block phenotypes associated with the process of carcinogenesis. This approach was proposed using transgenic mouse models to develop strategies for the nutritional modulation and chemoprevention of cancer [167]. The focus of primary cancer prevention is to stop carcinogenesis at the earliest possible point in the pathway. This approach can be applied to using in vitro model systems of these various stages to understand the molecular mechanisms of obesity and cancer risk. The advantage in using these systems is that the response of cells possessing various transformations can be compared to "normal cells". The key is to identify targets that are aberrant from normal to perturb for cancer prevention strategies. This approach would theoretically reduce the possibility of severe or unwanted side-effects when the target does not also destroy the normal cell mechanisms. Cell models can aid in the identification of those targets and inform rationale translation to animal and human studies.

\section{ACKNOWLEDGEMENT}

Research supported in part by the Michigan Agricultural Experiment Station and National Cancer Institute Grant Number R03CA130033.

\section{REFERENCES}

[1] Hedley AA, Ogden CL, Johnson CL, Carroll MD, Curtin LR, Flegal KM. Prevalence of overweight and obesity among US children, adolescents, and adults 1999-2002. JAMA 2004; 291(23): 2847-50.

[2] Wellman NS, Friedberg B. Causes and consequences of adult obesity: health, social and economic impacts in the United States. Asia Pac J Clin Nutr 2002; 11 (Suppl 8): S705-9.

[3] Executive Summary of The Third Report of The National Cholesterol Education Program (NCEP) Expert Panel on Detection, Evaluation, And Treatment of High Blood Cholesterol In Adults (Adult Treatment Panel III). JAMA 2001; 285(19): 2486-97.

[4] Calle EE, Kaaks R. Overweight, obesity and cancer: epidemiological evidence and proposed mechanisms. Nat Rev Cancer 2004; 4(8): 579-91.

[5] Rose DP, Haffner SM, Baillargeon J. Adiposity, the metabolic syndrome, and breast cancer in African-American and white American women. Endocr Rev 2007; 28(7): 763-77.

[6] Cowey S, Hardy RW. The metabolic syndrome: A high-risk state for cancer? Am J Pathol 2006; 169(5): 1505-22.

[7] Goodwin PJ, Ennis M, Pritchard KI, et al. Fasting insulin and outcome in early-stage breast cancer: results of a prospective cohort study. J Clin Oncol 2002; 20(1): 42-51.

[8] Colangelo LA, Gapstur SM, Gann PH, Dyer AR, Liu K. Colorectal cancer mortality and factors related to the insulin resistance syndrome. Cancer Epidemiol Biomarkers Prev 2002; 11(4): 38591.

[9] Jaggers JR, Sui X, Hooker SP, et al. Metabolic syndrome and risk of cancer mortality in men. Eur J Cancer 2009; 45: 1831-1838.

[10] Munkholm P. Review article: the incidence and prevalence of colorectal cancer in inflammatory bowel disease. Aliment Pharmacol Ther 2003; 18(Suppl 2): 1-5.

[11] Bird CL, Ingles SA, Frankl HD, Lee ER, Longnecker MP, Haile RW. Serum lipids and adenomas of the left colon and rectum. Cancer Epidemiol Biomarkers Prev 1996; 5(8): 607-12.

[12] Manousos O, Souglakos J, Bosetti C, et al. IGF-I and IGF-II in relation to colorectal cancer. Int J Cancer 1999; 83(1): 15-7.

[13] Wei EK, Ma J, Pollak MN, et al. A prospective study of C-peptide, insulin-like growth factor-I, insulin-like growth factor binding protein-1, and the risk of colorectal cancer in women. Cancer Epidemiol Biomarkers Prev 2005; 14(4): 850-5.

[14] Clevers H. At the crossroads of inflammation and cancer. Cell 2004; 118(6): 671-4.

[15] Balkwill F, Coussens LM. Cancer: an inflammatory link. Nature 2004; 431(7007): 405-6.

[16] Fearon ER, Vogelstein B. A genetic model for colorectal tumorigenesis. Cell 1990; 61(5): 759-67.

[17] Kim JY, van de Wall E, Laplante M, et al. Obesity-associated improvements in metabolic profile through expansion of adipose tissue. J Clin Invest 2007; 117(9): 2621-37.

[18] Shai I, Schwarzfuchs D, Henkin Y, et al. Weight loss with a lowcarbohydrate, Mediterranean, or low-fat diet. N Engl J Med 2008; 359(3): 229-41.

[19] Birmingham JM, Busik JV, Hansen-Smith FM, Fenton JI. Novel mechanism for obesity-induced colon cancer progression. Carcinogenesis 2009; 30(4): 690-697.

[20] Fenton JI, Birmingham JM, Hursting SD, Hord NG. Adiponectin blocks multiple signaling cascades associated with leptin-induced cell proliferation in Apc Min/+ colon epithelial cells. Int J Cancer 2008; 122(11): 2437-45

[21] Fenton JI, Hord NG. Stage matters: choosing relevant model systems to address hypotheses in diet and cancer chemoprevention research. Carcinogenesis 2006; 27(5): 893-902.

[22] Fenton JI, Hord NG, Lavigne JA, Perkins SN, Hursting SD. Leptin, insulin-like growth factor-1, and insulin-like growth factor-2 are mitogens in ApcMin/+ but not Apc+/+ colonic epithelial cell lines. Cancer Epidemiol Biomarkers Prev 2005; 14(7): 1646-52.

[23] Fenton JI, Hursting SD, Perkins SN, Hord NG. Interleukin-6 production induced by leptin treatment promotes cell proliferation in an Apc (Min/+) colon epithelial cell line. Carcinogenesis 2006; 27(7): 1507-15.

[24] Fenton JI, Hursting SD, Perkins SN, Hord NG. Leptin induces an Apc genotype-associated colon epithelial cell chemokine production pattern associated with macrophage chemotaxis and activation. Carcinogenesis 2007; 28(2): 455-64.

[25] Fenton JI, Lavigne JA, Perkins SN, et al. Microarray analysis reveals that leptin induces autocrine/paracrine cascades to promote survival and proliferation of colon epithelial cells in an Apc genotype-dependent fashion. Mol Carcinog 2008; 4 7(1): 9-21.

[26] Ronti T, Lupattelli G, Mannarino E. The endocrine function of adipose tissue: an update. Clin Endocrinol (Oxf) 2006; 64(4): 35565 .

[27] Guerre-Millo M. Adipose tissue and adipokines: for better or worse. Diabetes Metab 2004; 30(1): 13-9.

[28] Rayner DV, Trayhurn P. Regulation of leptin production: sympathetic nervous system interactions. J Mol Med 2001; 79(1): 8-20.

[29] Grundy SM, Brewer HB, Jr., Cleeman JI, Smith SC, Jr., Lenfant C. Definition of metabolic syndrome: report of the National Heart, Lung, and Blood Institute/American Heart Association conference on scientific issues related to definition. Arterioscler Thromb Vasc Biol 2004; 24(2): e13-8.

[30] Bianchini F, Kaaks R, Vainio H. Overweight, obesity, and cancer risk. Lancet Oncol 2002; 3(9): 565-74.

[31] Inadera $\mathrm{H}$. The usefulness of circulating adipokine levels for the assessment of obesity-related health problems. Int J Med Sci 2008; 5(5): $248-62$ 
[32] Trayhurn P, Wood IS. Adipokines: inflammation and the pleiotropic role of white adipose tissue. Br J Nutr 2004; 92(3): 34755.

[33] Beltowski J, Jamroz-Wisniewska A, Widomska S. Adiponectin and its role in cardiovascular diseases. Cardiovase Hematol Disord Drug Targets 2008; 8(1): 7-46.

[34] Fantuzzi G. Adipose tissue, adipokines, and inflammation. J Allergy Clin Immunol 2005; 115(5): 911-9; quiz 20.

[35] Kahn BB, Flier JS. Obesity and insulin resistance. J Clin Invest 2000; 106(4): 473-81.

[36] Hursting SD, Lashinger LM, Wheatley KW, et al. Reducing the weight of cancer: mechanistic targets for breaking the obesitycarcinogenesis link. Best Pract Res Clin Endocrinol Metab 2008; 22(4): 659-69.

[37] Boyd DB. Insulin and cancer. Integr Cancer Ther 2003; 2(4): $315-$ 29.

[38] Moschos SJ, Mantzoros CS. The role of the IGF system in cancer: from basic to clinical studies and clinical applications. Oncology 2002; 63(4): 317-32.

[39] Samani AA, Yakar S, LeRoith D, Brodt P. The role of the IGF system in cancer growth and metastasis: overview and recent insights. Endocr Rev 2007; 28(1): 20-47.

[40] Hakam A, Yeatman TJ, Lu L, et al. Expression of insulin-like growth factor-1 receptor in human colorectal cancer. Hum Pathol 1999; 30(10): 1128-33.

[41] Jiang Y, Wang L, Gong W, et al. A high expression level of insulin-like growth factor I receptor is associated with increased expression of transcription factor $\mathrm{Sp} 1$ and regional lymph node metastasis of human gastric cancer. Clin Exp Metastasis 2004; 21(8): 755-64.

[42] Kornprat P, Rehak P, Ruschoff J, Langner C. Expression of IGF-I, IGF-II, and IGF-IR in gallbladder carcinoma. A systematic analysis including primary and corresponding metastatic tumours. J Clin Pathol 2006; 59(2): 202-6.

[43] Xie Y, Skytting B, Nilsson G, Brodin B, Larsson O. Expression of insulin-like growth factor-1 receptor in synovial sarcoma: association with an aggressive phenotype. Cancer Res 1999; 59(15): 3588-91.

[44] All-Ericsson C, Girnita L, Seregard S, Bartolazzi A, Jager MJ, Larsson O. Insulin-like growth factor-1 receptor in uveal melanoma: a predictor for metastatic disease and a potential therapeutic target. Invest Ophthalmol Vis Sci 2002; 43(1): 1-8.

[45] Aloulou N, Bastuji-Garin S, Le Gouvello S, et al. Involvement of the leptin receptor in the immune response in intestinal cancer. Cancer Res 2008; 68(22): 9413-22.

[46] Huang L, Li C. Leptin: a multifunctional hormone. Cell Res 2000; 10(2): 81-92.

[47] Mark AL, Correia ML, Rahmouni K, Haynes WG. Loss of leptin actions in obesity: two concepts with cardiovascular implications. Clin Exp Hypertens 2004; 26(7-8): 629-36.

[48] Garofalo C, Surmacz E. Leptin and cancer. J Cell Physiol. 2006; 207(1): 12-22.

[49] Cao R, Brakenhielm E, Wahlestedt C, Thyberg J, Cao Y. Leptin induces vascular permeability and synergistically stimulates angiogenesis with FGF-2 and VEGF. Proc Natl Acad Sci USA 2001; 98(11): 6390-5.

[50] Artwohl M, Roden M, Holzenbein T, Freudenthaler A, Waldhausl W, Baumgartner-Parzer SM. Modulation by leptin of proliferation and apoptosis in vascular endothelial cells. Int J Obes Relat Metab Disord 2002; 26(4): 577-80.

[51] Mohamed-Ali V, Goodrick S, Rawesh A, et al. Subcutaneous adipose tissue releases interleukin-6, but not tumor necrosis factoralpha, in vivo. J Clin Endocrinol Metab 1997; 82(12): 4196-200.

[52] Greenstein AS, Khavandi K, Withers SB, et al. Local inflammation and hypoxia abolish the protective anticontractile properties of perivascular fat in obese patients. Circulation 2009 31; 119(12): 1661-70.

[53] Kim JH, Bachmann RA, Chen J. Interleukin-6 and insulin resistance. Vitam Horm 2009; 80: 613-33.

[54] Park HS, Park JY, Yu R. Relationship of obesity and visceral adiposity with serum concentrations of CRP, TNF-alpha and IL-6. Diabetes Res Clin Pract 2005; 69(1): 29-35.

[55] Syed V, Ulinski G, Mok SC, Ho SM. Reproductive hormoneinduced, STAT3-mediated interleukin 6 action in normal and malignant human ovarian surface epithelial cells. J Natl Cancer Inst 2002; 94(8): 617-29.

[56] Sriuranpong V, Park JI, Amornphimoltham P, Patel V, Nelkin BD, Gutkind JS. Epidermal growth factor receptor-independent constitutive activation of STAT3 in head and neck squamous cell carcinoma is mediated by the autocrine/paracrine stimulation of the interleukin 6/gp130 cytokine system. Cancer Res 2003; 63(11): 2948-56.

[57] Giri D, Ozen M, Ittmann M. Interleukin-6 is an autocrine growth factor in human prostate cancer. Am J Pathol 2001; 159(6): 215965.

[58] Li YY, Hsieh LL, Tang RP, Liao SK, Yeh KY. Interleukin-6 (IL-6) released by macrophages induces IL- 6 secretion in the human colon cancer HT-29 cell line. Hum Immunol 2009; 70(3): 151-8.

[59] Tempfer C, Zeisler H, Sliutz G, Haeusler G, Hanzal E, Kainz C. Serum evaluation of interleukin 6 in ovarian cancer patients. Gynecol Oncol 1997; 66(1): 27-30.

[60] Yokoe T, Iino Y, Takei H, et al. Changes of cytokines and thyroid function in patients with recurrent breast cancer. Anticancer Res 1997; 17(1B): 695-9.

[61] Goydos JS, Brumfield AM, Frezza E, Booth A, Lotze MT, Carty SE. Marked elevation of serum interleukin-6 in patients with cholangiocarcinoma: validation of utility as a clinical marker. Ann Surg 1998; 227(3): 398-404.

[62] Preti HA, Cabanillas F, Talpaz M, Tucker SL, Seymour JF, Kurzrock R. Prognostic value of serum interleukin-6 in diffuse large-cell lymphoma. Ann Intern Med 1997; 127(3): 186-94.

[63] Dowlati A, Levitan N, Remick SC. Evaluation of interleukin-6 in bronchoalveolar lavage fluid and serum of patients with lung cancer. J Lab Clin Med 1999; 134(4):405-9.

[64] Mouawad R, Benhammouda A, Rixe O, et al. Endogenous interleukin 6 levels in patients with metastatic malignant melanoma: correlation with tumor burden. Clin Cancer Res 1996; 2(8): 1405-9.

[65] Wierzbowska A, Urbanska-Rys H, Robak T. Circulating IL-6-type cytokines and sIL-6R in patients with multiple myeloma. Br J Haematol 1999; 105(2): 412-9.

[66] Okada S, Okusaka T, Ishii H, et al. Elevated serum interleukin-6 levels in patients with pancreatic cancer. Jpn J Clin Oncol 1998; 28(1): $12-5$.

[67] Nakashima J, Tachibana M, Horiguchi Y, et al. Serum interleukin 6 as a prognostic factor in patients with prostate cancer. Clin Cancer Res 2000; 6(7): 2702-6.

[68] Blay JY, Rossi JF, Wijdenes J, et al. Role of interleukin-6 in the paraneoplastic inflammatory syndrome associated with renal-cell carcinoma. Int J Cancer 1997; 72(3): 424-30.

[69] Yamauchi T, Kamon J, Minokoshi Y, et al. Adiponectin stimulates glucose utilization and fatty-acid oxidation by activating AMPactivated protein kinase. Nat Med 2002; 8(11): 1288-95.

[70] Bottner A, Kratzsch J, Muller G, et al. Gender differences of adiponectin levels develop during the progression of puberty and are related to serum androgen levels. J Clin Endocrinol Metab 2004; 89(8): 4053-61.

[71] Suzuki S, Wilson-Kubalek EM, Wert D, Tsao TS, Lee DH. The oligomeric structure of high molecular weight adiponectin. FEBS Lett 2007; 581(5): 809-14.

[72] Pajvani UB, Hawkins M, Combs TP, et al. Complex distribution, not absolute amount of adiponectin, correlates with thiazolidinedione-mediated improvement in insulin sensitivity. J Biol Chem 2004; 279(13): 12152-62.

[73] Koerner A, Kratzsch J, Kiess W. Adipocytokines: leptin-the classical, resistin-the controversical, adiponectin-the promising, and more to come. Best Pract Res Clin Endocrinol Metab 2005; 9(4): 525-46.

[74] Beltowski J. Adiponectin and resistin--new hormones of white adipose tissue. Med Sci Monit 2003; 9(2): RA55-61.

[75] Yamauchi T, Kamon J, Waki H, et al. The fat-derived hormone adiponectin reverses insulin resistance associated with both lipoatrophy and obesity. Nat Med 2001; 7(8): 941-6.

[76] Hu E, Liang P, Spiegelman BM. AdipoQ is a novel adiposespecific gene dysregulated in obesity. J Biol Chem 1996; 271(18): 10697-703.

[77] Kelesidis I, Kelesidis T, Mantzoros CS. Adiponectin and cancer: a systematic review. Br J Cancer 2006; 94(9): 1221-5. 
[78] Yokota T, Oritani K, Takahashi I, et al. Adiponectin, a new member of the family of soluble defense collagens, negatively regulates the growth of myelomonocytic progenitors and the functions of macrophages. Blood 2000; 96(5): 1723-32.

[79] Goldstein BJ, Scalia R. Adiponectin: A novel adipokine linking adipocytes and vascular function. J Clin Endocrinol Metab 2004; 89(6): 2563-8.

[80] Brakenhielm E, Veitonmaki N, Cao R, et al. Adiponectin-induced antiangiogenesis and antitumor activity involve caspase-mediated endothelial cell apoptosis. Proc Natl Acad Sci USA 2004; 101(8): 2476-81.

[81] Wang Y, Lam KS, Xu JY, et al. Adiponectin inhibits cell proliferation by interacting with several growth factors in an oligomerization-dependent manner. J Biol Chem 2005; 280(18): 18341-7.

[82] Lorincz AM, Sukumar S. Molecular links between obesity and breast cancer. Endocr Relat Cancer 2006; 13(2): 279-92.

[83] Nunez NP, Perkins SN, Smith NC, et al. Obesity accelerates mouse mammary tumor growth in the absence of ovarian hormones. Nutr Cancer 2008; 60(4): 534-41

[84] Rose DP, Komninou D, Stephenson GD. Obesity, adipocytokines, and insulin resistance in breast cancer. Obes Rev 2004; 5(3): 15365.

[85] Yee D, Lee AV. Crosstalk between the insulin-like growth factors and estrogens in breast cancer. J Mammary Gland Biol Neoplasia 2000; 5(1): 107-15.

[86] Song RX, Zhang Z, Chen Y, Bao Y, Santen RJ. Estrogen signaling via a linear pathway involving insulin-like growth factor I receptor, matrix metalloproteinases, and epidermal growth factor receptor to activate mitogen-activated protein kinase in MCF-7 breast cancer cells. Endocrinology 2007; 148(8): 4091-101.

[87] Railo MJ, von Smitten K, Pekonen F. The prognostic value of insulin-like growth factor-I in breast cancer patients. Results of a follow-up study on 126 patients. Eur J Cancer 1994; 30A(3): 30711.

[88] Werner H, Maor S. The insulin-like growth factor-I receptor gene: a downstream target for oncogene and tumor suppressor action. Trends Endocrinol Metab 2006; 17(6): 236-42.

[89] Gunter MJ, Hoover DR, Yu H, et al. Insulin, insulin-like growth factor-I, and risk of breast cancer in postmenopausal women. J Natl Cancer Inst 2009; 101(1): 48-60.

[90] Schernhammer ES, Holly JM, Pollak MN, Hankinson SE. Circulating levels of insulin-like growth factors, their binding proteins, and breast cancer risk. Cancer Epidemiol Biomarkers Prev 2005; 14(3): 699-704.

[91] McTernan PG, Anwar A, Eggo MC, Barnett AH, Stewart PM, Kumar S. Gender differences in the regulation of $\mathrm{P} 450$ aromatase expression and activity in human adipose tissue. Int $\mathrm{J}$ Obes Relat Metab Disord 2000; 24(7): 875-81.

[92] Dieudonne MN, Machinal-Quelin F, Serazin-Leroy V, Leneveu MC, Pecquery R, Giudicelli Y. Leptin mediates a proliferative response in human MCF7 breast cancer cells. Biochem Biophys Res Commun 2002; 293(1): 622-8.

[93] Laud K, Gourdou I, Pessemesse L, Peyrat JP, Djiane J. Identification of leptin receptors in human breast cancer: functional activity in the T47-D breast cancer cell line. Mol Cell Endocrinol 2002; 188(1-2): 219-26.

[94] Ishikawa M, Kitayama J, Nagawa H. Enhanced expression of leptin and leptin receptor (OB-R) in human breast cancer. Clin Cancer Res 2004; 10(13): 4325-31.

[95] Lee WM, Lu S, Medline A, Archer MC. Susceptibility of lean and obese Zucker rats to tumorigenesis induced by N-methyl-Nnitrosourea. Cancer Lett 2001; 162(2): 155-60.

[96] Cleary MP, Juneja SC, Phillips FC, Hu X, Grande JP, Maihle NJ. Leptin receptor-deficient MMTV-TGF-alpha/Lepr(db)Lepr(db) female mice do not develop oncogene-induced mammary tumors. Exp Biol Med (Maywood) 2004; 229(2): 182-93.

[97] Cleary MP, Phillips FC, Getzin SC, et al. Genetically obese MMTV-TGF-alpha/Lep(ob)Lep(ob) female mice do not develop mammary tumors. Breast Cancer Res Treat 2003; 77(3): 205-15.

[98] Catalano S, Marsico S, Giordano C, et al. Leptin enhances, via AP1 , expression of aromatase in the MCF-7 cell line. J Biol Chem $2003 ; 278(31): 28668-76$
[99] Catalano S, Mauro L, Marsico S, et al. Leptin induces, via ERK1/ERK2 signal, functional activation of estrogen receptor alpha in MCF-7 cells. J Biol Chem 2004; 279(19): 19908-15.

[100] Perera C, Chin H, Duru N, Camarillo I. Leptin regulated gene expression in MCF-7 breast cancer cells: mechanistic insights into leptin regulated mammary tumor growth and progression. J Endocrinol 2008; 199(2): 221-233.

[101] Okumura M, Yamamoto M, Sakuma H, et al. Leptin and high glucose stimulate cell proliferation in MCF-7 human breast cancer cells: reciprocal involvement of PKC-alpha and PPAR expression. Biochim Biophys Acta 2002; 1592(2): 107-16.

[102] Saxena NK, Taliaferro-Smith L, Knight BB, et al. Bidirectional crosstalk between leptin and insulin-like growth factor-I signaling promotes invasion and migration of breast cancer cells via transactivation of epidermal growth factor receptor. Cancer Res 2008; 68(23): 9712-22.

[103] Dos Santos E, Benaitreau D, Dieudonne MN, et al. Adiponectin mediates an antiproliferative response in human MDA-MB 231 breast cancer cells. Oncol Rep 2008; 20(4): 971-7.

[104] Wang Y, Lam JB, Lam KS, et al. Adiponectin modulates the glycogen synthase kinase-3beta/beta-catenin signaling pathway and attenuates mammary tumorigenesis of MDA-MB-231 cells in nude mice. Cancer Res 2006; 66(23): 11462-70.

[105] Treeck O, Lattrich C, Juhasz-Boess I, Buchholz S, Pfeiler G, Ortmann O. Adiponectin differentially affects gene expression in human mammary epithelial and breast cancer cells. $\mathrm{Br} \mathrm{J}$ Cancer 2008; 99(8): 1246-50.

[106] Denzel MS, Hebbard LW, Shostak G, Shapiro L, Cardiff RD, Ranscht B. Adiponectin deficiency limits tumor vascularization in the MMTV-PyV-mT mouse model of mammary cancer. Clin Cancer Res 2009; 15(10): 3256-64.

[107] Landskroner-Eiger S, Qian B, Muise ES, et al. Proangiogenic contribution of adiponectin toward mammary tumor growth in vivo. Clin Cancer Res 2009; 15(10): 3265-76.

[108] Hsing AW, Sakoda LC, Chua S, Jr. Obesity, metabolic syndrome, and prostate cancer. Am J Clin Nutr 2007; 86(3): s843-57.

[109] Tokuda Y, Satoh Y, Fujiyama C, Toda S, Sugihara H, Masaki Z. Prostate cancer cell growth is modulated by adipocyte-cancer cell interaction. BJU Int 2003 May;91(7):716-20.

[110] Goncharov NP, Katsya GV, Chagina NA, Gooren LJ. Testosterone and obesity in men under the age of 40 years. Andrologia 2009; 41(2): 76-83.

[111] Dadras SS, Cai X, Abasolo I, Wang Z. Inhibition of 5alphareductase in rat prostate reveals differential regulation of androgenresponse gene expression by testosterone and dihydrotestosterone. Gene Expr 2001; 9(4-5): 183-94.

[112] Platz EA, Leitzmann MF, Rifai N, et al. Sex steroid hormones and the androgen receptor gene $\mathrm{CAG}$ repeat and subsequent risk of prostate cancer in the prostate-specific antigen era. Cancer Epidemiol Biomarkers Prev 2005; 14(5): 1262-9.

[113] Giovannucci E, Rimm EB, Liu Y, et al. Body mass index and risk of prostate cancer in U.S. health professionals. J Natl Cancer Inst 2003; 95(16): 1240-4.

[114] Gong Z, Neuhouser ML, Goodman PJ, et al. Obesity, diabetes, and risk of prostate cancer: results from the prostate cancer prevention trial. Cancer Epidemiol Biomarkers Prev 2006; 15(10): 1977-83.

[115] Frankenberry KA, Somasundar P, McFadden DW, Vona-Davis LC. Leptin induces cell migration and the expression of growth factors in human prostate cancer cells. Am J Surg 2004; 188(5): 560-5.

[116] Somasundar P, Frankenberry KA, Skinner H, et al. Prostate cancer cell proliferation is influenced by leptin. J Surg Res 2004; 118(1): 71-82.

[117] Hoda MR, Popken G. Mitogenic and anti-apoptotic actions of adipocyte-derived hormone leptin in prostate cancer cells. BJU Int 2008; 102(3): 383-8.

[118] Onuma M, Bub JD, Rummel TL, Iwamoto Y. Prostate cancer celladipocyte interaction: leptin mediates androgen-independent prostate cancer cell proliferation through c-Jun NH2-terminal kinase. J Biol Chem 2003; 278(43): 42660-7.

[119] Colombatti M, Grasso S, Porzia A, et al. The prostate specific membrane antigen regulates the expression of IL-6 and CCL5 in prostate tumour cells by activating the MAPK pathways. PLoS ONE 2009; 4(2): e4608. 
[120] Malinowska K, Neuwirt H, Cavarretta IT, et al. Interleukin-6 stimulation of growth of prostate cancer in vitro and in vivo through activation of the androgen receptor. Endocr Relat Cancer 2009; 16(1): 155-69.

[121] Steiner H, Godoy-Tundidor S, Rogatsch H, et al. Accelerated in vivo growth of prostate tumors that up-regulate interleukin- 6 is associated with reduced retinoblastoma protein expression and activation of the mitogen-activated protein kinase pathway. Am J Pathol 2003; 162(2): 655-63.

[122] Huffman DM, Johnson MS, Watts A, Elgavish A, Eltoum IA, Nagy TR. Cancer progression in the transgenic adenocarcinoma of mouse prostate mouse is related to energy balance, body mass, and body composition, but not food intake. Cancer Res 2007; 67(1): 417-24.

[123] Miyazaki T, Bub JD, Iwamoto Y. c-Jun NH(2)-terminal kinase mediates leptin-stimulated androgen-independent prostate cancer cell proliferation via signal transducer and activator of transcription 3 and Akt. Biochim Biophys Acta 2008; 1782(10): 593-604.

[124] Arisan ED, Arisan S, Atis G, Palavan-Unsal N, Ergenekon E. Serum adipocytokine levels in prostate cancer patients. Urol Int 2009; 82(2): 203-8.

[125] Zakikhani M, Dowling RJ, Sonenberg N, Pollak MN. The effects of adiponectin and metformin on prostate and colon neoplasia involve activation of AMP-activated protein kinase. Cancer Prev Res (Phila Pa) 2008; 1(5): 369-75.

[126] Bub JD, Miyazaki T, Iwamoto Y. Adiponectin as a growth inhibitor in prostate cancer cells. Biochem Biophys Res Commun 2006; 340(4): 1158-66.

[127] Amemori S, Ootani A, Aoki S, et al. Adipocytes and preadipocytes promote the proliferation of colon cancer cells in vitro. Am J Physiol Gastrointest Liver Physiol 2007; 292(3): G923-9.

[128] Miyamoto S, Yasui Y, Tanaka T, Ohigashi H, Murakami A. Suppressive effects of nobiletin on hyperleptinemia and colitisrelated colon carcinogenesis in male ICR mice. Carcinogenesis 2008; 29(5): 1057-63.

[129] Schnabele K, Roser S, Rechkemmer G, Hauner H, Skurk T. Effects of adipocyte-secreted factors on cell cycle progression in HT29 cells. Eur J Nutr 2009; 48(3):154-61.

[130] Ogunwobi OO, Beales IL. The anti-apoptotic and growth stimulatory actions of leptin in human colon cancer cells involves activation of JNK mitogen activated protein kinase, JAK2 and PI3 kinase/Akt. Int J Colorectal Dis 2007; 22(4): 401-9.

[131] Hoda MR, Keely SJ, Bertelsen LS, Junger WG, Dharmasena D, Barrett KE. Leptin acts as a mitogenic and antiapoptotic factor for colonic cancer cells. Br J Surg 2007; 94(3): 346-54.

[132] Abolhassani M, Aloulou N, Chaumette MT, et al. Leptin receptorrelated immune response in colorectal tumors: the role of colonocytes and interleukin-8. Cancer Res 2008 :68(22): 9423-32.

[133] Aparicio T, Kotelevets L, Tsocas A, et al. Leptin stimulates the proliferation of human colon cancer cells in vitro but does not promote the growth of colon cancer xenografts in nude mice or intestinal tumorigenesis in Apc(Min/+) mice. Gut 2005; 54(8): 1136-45.

[134] Rouet-Benzineb P, Aparicio T, Guilmeau S, et al. Leptin counteracts sodium butyrate-induced apoptosis in human colon cancer HT-29 cells via NF-kappaB signaling. J Biol Chem 2004; 279(16): 16495-502.

[135] Jaffe T, Schwartz B. Leptin promotes motility and invasiveness in human colon cancer cells by activating multiple signal-transduction pathways. Int J Cancer 2008; 123(11): 2543-56.

[136] Grivennikov S, Karin E, Terzic J, et al. IL-6 and Stat3 are required for survival of intestinal epithelial cells and development of colitisassociated cancer. Cancer Cell 2009; 15(2): 103-13.

[137] Mentor-Marcel RA, Bobe G, Barrett KG, et al. Inflammationassociated serum and colon markers as indicators of dietary attenuation of colon carcinogenesis in ob/ob mice. Cancer Prev Res (Phila Pa) 2009; 2(1): 60-9.

[138] Kuilman T, Michaloglou C, Vredeveld LC, et al. Oncogeneinduced senescence relayed by an interleukin-dependent inflammatory network. Cell 2008; 133(6): 1019-31.

[139] Fujisawa T, Endo H, Tomimoto A, et al. Adiponectin suppresses colorectal carcinogenesis under the high-fat diet condition. Gut 2008; 57(11): 1531-8.
[140] Nishihara T, Matsuda M, Araki H, et al. Effect of adiponectin on murine colitis induced by dextran sulfate sodium. Gastroenterology 2006; 131(3): 853-61.

[141] Fayad R, Pini M, Sennello JA, et al. Adiponectin deficiency protects mice from chemically induced colonic inflammation. Gastroenterology 2007; 132(2): 601-14.

[142] Pini M, Gove ME, Fayad R, Cabay RJ, Fantuzzi G. Adiponectin deficiency does not affect development and progression of spontaneous colitis in IL-10 knockout mice. Am J Physiol Gastrointest Liver Physiol 2009; 296(2): G382-7.

[143] Jat PS, Noble MD, Ataliotis P, et al. Direct derivation of conditionally immortal cell lines from an $\mathrm{H}-2 \mathrm{~Kb}$-tsA58 transgenic mouse. Proc Natl Acad Sci USA 1991; 88(12): 5096-100.

[144] Whitehead RH, VanEeden PE, Noble MD, Ataliotis P, Jat PS. Establishment of conditionally immortalized epithelial cell lines from both colon and small intestine of adult H-2Kb-tsA58 transgenic mice. Proc Natl Acad Sci USA 1993; 90(2): 587-91.

[145] Whitehead RH, Joseph JL. Derivation of conditionally immortalized cell lines containing the Min mutation from the normal colonic mucosa and other tissues of an "Immortomouse"/Min hybrid. Epithelial Cell Biol 1994; 3(3): 11925 .

[146] Kinzler KW, Vogelstein B. Lessons from hereditary colorectal cancer. Cell 1996; 87(2): 159-70.

[147] Moser AR, Pitot HC, Dove WF. A dominant mutation that predisposes to multiple intestinal neoplasia in the mouse. Science 1990; 247(4940): 322-4.

[148] Fodde R, Smits R, Clevers H. APC, signal transduction and genetic instability in colorectal cancer. Nat Rev Cancer 2001; 1(1): 55-67.

[149] Husoy T, Knutsen HK, Cruciani V, et al. Connexin43 is overexpressed in $\mathrm{Apc}(\mathrm{Min} /+)$-mice adenomas and colocalises with COX-2 in myofibroblasts. Int J Cancer 2005; 116(3): 351-8.

[150] D'Abaco GM, Whitehead RH, Burgess AW. Synergy between Apc min and an activated ras mutation is sufficient to induce colon carcinomas. Mol Cell Biol 1996; 16(3):884-91.

[151] Xu Y, Pasche B. TGF-beta signaling alterations and susceptibility to colorectal cancer. Hum Mol Genet 2007; 16 Spec No 1: R14-20.

[152] Becker C, Fantini MC, Neurath MF. TGF-beta as a T cell regulator in colitis and colon cancer. Cytokine Growth Factor Rev 2006; 17(1-2): 97-106.

[153] Mithani SK, Balch GC, Shiou SR, Whitehead RH, Datta PK, Beauchamp RD. Smad3 has a critical role in TGF-beta-mediated growth inhibition and apoptosis in colonic epithelial cells. J Surg Res 2004; 117(2): 296-305.

[154] Maggio-Price L, Treuting P, Zeng W, Tsang M, Bielefeldt-Ohmann $\mathrm{H}$, Iritani BM. Helicobacter infection is required for inflammation and colon cancer in SMAD3-deficient mice. Cancer Res 2006; 66(2): 828-38.

[155] Munoz N, Baek J, Grady W. TGF-beta has paradoxical and context dependent effects on proliferation and anoikis in human colorectal cancer cell lines. Growth Factors. [Research Support, N.I.H., Extramural Research Support, Non-U.S. Gov't Research Support, U.S. Gov't, Non-P.H.S.] 2008; 26(5): 254-62.

[156] Corbett TH, Griswold DP, Jr., Roberts BJ, Peckham JC, Schabel FM, Jr. Tumor induction relationships in development of transplantable cancers of the colon in mice for chemotherapy assays, with a note on carcinogen structure. Cancer Res 1975; 35(9): 2434-9.

[157] Pajtasz-Piasecka E, Szyda A, Rossowska J, et al. Loss of tumorigenicity of murine colon carcinoma MC38/0 cell line after transduction with a retroviral vector carrying murine IL-12 genes. Folia Biol (Praha) 2004; 50(1): 7-14.

[158] Fenton JI, Hursting SD, Perkins SN, Hord NG. Leptin induces an Apc genotype-associated colon epithelial cell chemokine production pattern associated with macrophage chemotaxis and activation. Carcinogenesis 2006; 28(2): 455-464.

[159] Brown KA, Back SJ, Ruchelli ED, et al. Lamina propria and circulating interleukin-6 in newly diagnosed pediatric inflammatory bowel disease patients. Am J Gastroenterol 2002; 97(10): 2603-8.

[160] Seegert D, Rosenstiel P, Pfahler H, Pfefferkorn P, Nikolaus S, Schreiber S. Increased expression of IL-16 in inflammatory bowel disease. Gut 2001; 48(3): 326-32. 
[161] Naito $\mathrm{Y}$, Takagi $\mathrm{T}$, Uchiyama $\mathrm{K}$, et al. Reduced intestinal inflammation induced by dextran sodium sulfate in interleukin-6deficient mice. Int J Mol Med 2004; 14(2): 191-6.

[162] Wilson J, Balkwill F. The role of cytokines in the epithelial cancer microenvironment. Semin Cancer Biol 2002; 12(2): 113-20.

[163] Giovannucci E. Metabolic syndrome, hyperinsulinemia, and colon cancer: a review. Am J Clin Nutr 2007; 86(3): s836-42.

[164] Pisani P. Hyper-insulinaemia and cancer, meta-analyses of epidemiological studies. Arch Physiol Biochem 2008; 114(1): 6370.
[165] Kang JH, Lee YY, Yu BY, et al. Adiponectin induces growth arrest and apoptosis of MDA-MB-231 breast cancer cell. Arch Pharm Res 2005; 28(11): 1263-9.

[166] Hanahan D, Weinberg RA. The hallmarks of cancer. Cell 2000; 100(1): 57-70.

[167] Hursting SD, Slaga TJ, Fischer SM, DiGiovanni J, Phang JM. Mechanism-based cancer prevention approaches: targets, examples, and the use of transgenic mice. J Natl Cancer Inst 1999; 91(3): 21525 .

Received: September 29, 2009

(C) Fenton et al.; Licensee Bentham Open.

This is an open access article licensed under the terms of the Creative Commons Attribution Non-Commercial License (http://creativecommons.org/licenses/by$\mathrm{nc} / 3.0 /$ ), which permits unrestricted, non-commercial use, distribution and reproduction in any medium, provided the work is properly cited. 